\title{
The Role of Comics in Elementary School Science Education
}

\author{
Hong-Yii Phoon, Roslinawati Roslan, Masitah Shahrill (*), Hardimah Mohd. Said \\ Sultan Hassanal Bolkiah Institute of Education, Universiti Brunei Darussalam, \\ Brunei Darussalam
}

\begin{abstract}
Received: March 27, 2020
Revised: May 09, 2020

Accepted: May 18, 2020
\end{abstract}

\begin{abstract}
Comic books can be and are produced mainly for science communication. Comics are more favorable to be read by the students as comics engaged students in reading compared to thick science textbooks. This study explored the role of comics as an aid in teaching elementary school science on the topic of 'Plant Systems' using an action research approach. A total of 18 Grade 5 students from one of the elementary schools in Brunei Darussalam participated in the study. A 15-page fully colored comic featuring a leaf fairy character called 'Nym' was utilized to teach the students alongside various activities about plants during the intervention lessons. A pre-test was administered before the lesson to establish their existing knowledge of the topic, and then a post-test administered after all the intervention lessons were completed. The results from the achievement scores analyzed between the pre- and post-tests indicated that the students' knowledge on 'Plant Systems' improved significantly. The students were found to be interested, engaged and enthusiastic in the use of comics as revealed from the thematic analysis of the interviews. There are also vast potentials for comics to be used regularly to support learning in sciencerelated classrooms.

Keywords: Comics, Elementary School, Teaching and learning, Student's performance, Science Education
\end{abstract}

(*) Corresponding Author: $\quad$ masitah.shahrill@ubd.edu.bn

How to Cite: Phoon, H., et al. (2020). The role of comics in elementary school science education. Formatif: Jurnal Ilmiah Pendidikan MIPA, 10 (2), 67-76. http://dx.doi.org/10.30998/formatif.v10i2.6257

\section{INTRODUCTION}

For the average layman, the word comics may bring to mind the muscle-bound superheroes of Marvel and DC such as Batman, Superman or the Avengers, the paper books of Archie, or perhaps the whimsical journeys of The Adventures of Tintin and Asterix, depending on what they grew up. Younger generations may be more familiar with Manga comics originating from Japan that are unique in styles, format and presentation utilized to stand out from their Western creations. Either way, the comic medium in its various forms shares many similarities regardless of culture and artistic style. However, to ask said average layman precisely what the comics medium is, the answer would be as varied as the individuals themselves since they will attempt to define it according to their own experiences.

It is not unreasonable to propose comics as a teaching resource. Comics have always appealed to children and young adults, especially more so with the recent surge in popularity for comic books due to the success of Marvel's 'comic book' movies. The comic is found to increase students' engagement and motivation in learning (BoltonGary, 2012; Hosler \& Boomer, 2011). It was also reported that cultivating intrinsic motivation is in itself an important issue, in which students with higher academic core motivation possess competency in the school, between childhood and adolescence and 
across varied populations (Gottfried et al., 2009). Having a positive attitude, being engaged and motivated have been listed as the success factors in Mathematics and Science (Tapa et al., 2017; Leong et al., 2016; Othman et al., 2016; Singh et al., 2002). Venturini (2004) cited seven studies by stating, "Attitudes towards Science degrade as students progressed through school" (p. 11). Not only that, but all the learning process should also be more challenging and pleasing to encourage students to spark their interest, creativity development whether it is physical and psychological (Jampel et al., 2018). The conclusions that have been formulated from the consistency of these studies are harsh in delivering their verdict (Osborne et al., 2003). Explanations for this phenomenon range from school science not being observed as hands-on or significant (Barmby et al., 2008). Teacher encouragement of science and student participation in science activities and peer attitude could also explain variations in attitudes (George, 2006). It was commented that students nowadays are enthused by everyday issues if it pertains in the context, which is set meaningfully (Trnová et al., 2013). The comic medium is well suited for this purpose, besides its visual appeal and use of cartoons (Topkaya \& Doğan, 2020; Adnan et al., 2019; Matuk et al., 2019).

It was a widely reported phenomenon that students' interest in the science subject declining in the transitioning stages from elementary to secondary schooling (Akram et al., 2017; Tröbst et al., 2016; Potvin \& Hasni, 2014) that is even prevalent in other countries (Xie \& Achen, 2009). And it is possibly one factor for students' declining grades in school in the subject. McCloud (1993) argued that one aspect of comics that makes it suitable for communicating various messages is that comics can focus the reader's attention on an idea due to the simplification of the art by "de-emphasizing the appearance of the physical world in favour of the idea of form" (p. 41). And thus, it is placing the comic in the world of concepts instead. The significance of this is that comics can be used to convey ideas appealingly. Tajmel (2010) reported German native speakers to have difficulties with their mother tongue, especially if they come from a lower social or economic background and Seedhouse (2004) discussed how students with lower linguistic skills have fewer possibilities of actively and successfully participating in classroom activities. Hence the idea of using comics as its definition above states to act as a means of communicating scientific concepts in a palatable manner that is of interest to students is not unfounded. Although the most popular use of comics may be to express ideas in the form of a story, the medium itself is not restricted to serving the purpose of entertainment, as shown by its utilization in political, instructional and informational context. The reasoning for this lies with how the youth of today's society now prefer visuals. Accessibility to the Internet has defined the way messages are conveyed, mostly as images especially in the form of 'memes', and students are less likely to read a lengthy text when an image sums up a message much more succinctly. It should come as no surprise that if a topic is not attractive, students are likely to skip passages to try and finish the text quickly (Trnová et al., 2013; Grunwald, 2003). Comic books can be and are produced mainly for science communication. Comics are better than the textbooks, especially the thick one that contains a lot of information and materials that can demotivate the students and refused to read it (Lesmono et al., 2018). According to Tatalovic (2009), science comics are "comics which have as one of their main aims to communicate science or to educate the reader about some non-fictional scientific concept or theme. Even if this means using fictional techniques and narratives to convey the nonfictional information" (p. 4).

As explained earlier, there are many benefits of using comic in engaging and motivating students to learn in science. Due to the challenges of learning science in English in Brunei, students have difficulties understanding science topics quickly (Roslan et al., 2018). Because of this, comics have the potential in supporting and engaging 
students to learn science in Brunei Darussalam. This study is among the only few studies reported in using comics, which was created by the first author in Brunei classroom where the students' first language is not the English language. Moreover, using comics on the science concept 'Plant Systems' is not found elsewhere in the literature. The main goal of this study is to explore whether the use of comics could improve students' understanding of 'Plant Systems' and their views on the usage of the medium in the classroom regularly. The following two research questions guided this study: Firstly, how do the students view the use of comics in learning plant systems in science? Secondly, to what extent does using comics improve the students' knowledge of 'Plant Systems'?

\section{METHODS}

The study was carried out with a class of 18 Grade 5 students ( 7 male and 11 female) with the students' age ranging between 9 to 11 years old. The study site was a government elementary school located in the most populated district in Brunei. The class comprised average-ability students except for one special-needs student. For this study, the methodology employed concerns the use of action research. The four major steps implemented using action research are Planning, Implementation (Action), Observing and Reflecting.

Planning Stage - In this action research, the lessons were aimed for the students to identify the "Shoot system" and "Root system" by studying the comic. The first author created the comic using a script and planned out with a base storyboard to be able to fit the information required with the appropriate visuals to follow. The 15-page comics (refer to Appendix 1) is fully colored and features a leaf fairy character named Nym to 'talk' to the students as well as convey information that accompanies the visuals. Notably, this is to avoid large amounts of text that the students have to read passively. Instead, the information is being told to students by a character whose physical features leaned more towards humanoid than a plant. It was a deliberate aesthetic choice included by the first author to allow the students to connect to the character. The character design ensures that Nym, while still being a focus of the comic due to the moderate inclusion of bright, warm colors to balance out her mostly cool, darker palette, will still ultimately end up as a prop, or a vector of information. Rather than the comic is focusing solely on her. As Nym is mostly colored in de-saturated greens with a slight touch of reds and yellows, the comic background is a moderately saturated blue to balance out the palette.

The number of panels each page was kept down to five or lower so as not to introduce clutter to the overall page composition. According to Liu (2004), all the decorative function can help to improve the reader memory. All panels were kept in roughly a rectangular page; at the same time, compositions would allow for irregularly shaped panels to focus on content, the primary aim of the singular shape was to enable reading pace and transition remain even and consistent. The English language used in the comic is of the same level as the English language used in the textbook used by the class. If the students do not understand the meaning of the words, the teacher (also the first author) supplements the comics by explaining it to them. There were also hands-on practical incorporated into the lesson, such as examining a sliced tomato and identifying its features or searching for features in dissected flowers. It is mostly for the benefit of a real-life object that the students can compare to the pictures used in the comic.

Action and Observing Stages - Throughout the intervention lessons, the teacher is responsible for making observations of the students and their responses towards the lessons using a camera to video record the classroom throughout the lesson. These videos were later analyzed regarding the students' behavior during the lesson as qualitative data 
on the effects of using the comics with regards to student engagement and interest. At the end of the intervention lessons, after the post-test has been carried out, interviews with five randomly selected students were conducted. The interviews were electronically recorded and later transcribed verbatim.

Reflection Stage - This stage bases itself on the gathered data, such as the video recordings and the transcriptions of the interviews. And the teacher's experiences during the lessons on the difficulties of conducting such a lesson. The reflection process involves questioning the whole strategy and plan to improve on what is already known.

The questions used for the pre- and post-tests are mostly factual, requiring memory recall and focusing on the vocabulary used. The interviews consisted of four questions that were expanded based on the student's response to the questions. These were aimed at finding out the students' views on the use of comics during the lessons. For the data analysis procedure, the scores from the quantitative data were collected from both the pre- and post-test and collated into the SPSS Statistics software for analysis using a paired t-test. The interviews were analyzed for recurring themes to see if the students shared the same opinions and, if not, to discuss any reason for the differences.

All student names have been changed to pseudonyms to keep their identities confidential. And all recordings have not been shown or distributed to anyone else apart from the research team. Consent forms and letters were sent out to parents or guardians of the students before the study to ensure that the parents were well informed and gave permission to their child's participation in the study.

\section{RESULTS \& DISCUSSION}

\section{Results}

The students' responses to the interviews on the use of comics in learning science were analyzed using thematic analysis, and the following themes emerged.

Enjoyment - The first and most prominent theme that emerged from the students' responses to the interviews is enjoyment. All the students exclaimed that they enjoyed learning science through the use of comics, such as Hadi saying "Because it's very fun" when asked how he felt about the use of comics. Hamid, who answered with a similar statement, supported this. When asked why comics made the lesson fun, the responses had a few variations but were still mostly similar. Nurulain stated that it was because the comics "has cartoon, has pictures". Faiqah explained that comics made it easier to understand what was being taught. Hamid shared a similar opinion, citing that it helped with understanding. Though they could not specify exactly why this is so, they were sure that the comics had enabled them to expand their knowledge on the topic.

Engagement - Tying in with the above theme, when asked if the lesson was boring, the students disagreed and expressed an opposite opinion. This correlated with the video recordings of the classroom. The students fully engaged throughout the lesson when the teacher was going through the comics, the worksheets or the demonstrations with live objects. Whenever the character in the comics asked questions, the students would try to answer as if the teacher had initially asked. But treating the character as if she was a real person and enthusiastically attempting to answer organically. Observations from the video recordings show that the students looked forward to the lessons and were keen to learn the next subject. Their subject teacher has previously noted this class for their enthusiasm for science, which may also be a contributing factor. They indicated that the comics helped them understand the topic. When students saw the comics for the first time, they wanted to read it out loud on their own and were happy to take turns between 
the other classmates if they wanted to do so. The use of practical hands-on real objects as well as incorporating activities throughout the lesson based on answering Nym's questions and the accompaniment of visuals were also met with enthusiasm.

Positive View of using Comics in the Classroom - When asked about using comics in the classroom in the future, the students, in general, were keen about the prospective idea. Hamid and Faiqah were unilateral in stating that it would be "awesome" if that were to happen. The other students were less emphatic but equally excited about it. Only Ahmad expressed that they would not use comics in the classroom. Based on his response, it can be implied that in his opinion, reading comics would only be during his free time. He felt that the medium did not contain enough information to be educational. However, he did agree that if he were given the comics in the classroom, he would still be interested. He also mentioned money as a factor in preferring not to buy comics.

All in all, it would have been beneficial to expand the interviews by asking further questions on the views of reading comics in general, however, the interviews were focused on the usage of comics within the classroom to teach science. These findings are in line with that of previous studies regarding the use of comic books in the classroom carried out in a practical environment, such as Hosler and Boomer (2011), which examined the effect of comic books on student attitude and learning.

From Table 1, the average of the post-test scores is 3.2 times higher than the pretest scores. The standard deviation is also greater with the post-test scores, showing a larger variance of scores. Meanwhile, the test results in Table 2 are statistically significant $(\mathrm{P}<0.05)$, with values ranging from $15-32$ in a confidence interval of $95 \%$ and a $t$-value of 5.83.

Table 1. Mean and standard deviation of the pre- and post-test achievement scores

\begin{tabular}{cccccc}
\hline & Mean & N & Std. Deviation & $\begin{array}{c}\text { Std. Error } \\
\text { Mean }\end{array}$ \\
\hline Pair 1 & Post-test & 35.39 & 18 & 20.67 & 4.87 \\
& Pre-test & 11.88 & 18 & 6.42 & 1.51 \\
\hline
\end{tabular}

As displayed in Table 2, there is a significant difference in the achievement scores between the results of the pre- and post-tests. It demonstrates an improvement in the overall marks. Higher marks were obtained in the post-test in comparison to the pre-test. Analyzing the test papers also showed that the sections that were used as worksheets had higher marks for the post-test. While the exact specific impact of the use of the comics cannot be entirely measured with those results. It can be determined that the use of the comic, which was the primary tool for teaching that remained consistent for all three days of the intervention lesson, had a helping hand in the matter. If going by the interviews, the use of the comics encouraged students to be more engaged in the lesson; then it can be used as a starting point for learning support in science.

Table 2. Paired sample t-test results of achievement scores from pre- and post-test

\begin{tabular}{|c|c|c|c|c|c|c|c|c|}
\hline & & \multicolumn{5}{|c|}{ Paired Differences } & \multirow{3}{*}{$\mathrm{t} \quad \mathrm{df}$} & \multirow{3}{*}{$\begin{array}{l}\text { Sig. (2- } \\
\text { tailed) }\end{array}$} \\
\hline & & \multirow{2}{*}{ Mean } & \multirow{2}{*}{$\begin{array}{c}\text { Std. } \\
\text { Deviation }\end{array}$} & \multirow{2}{*}{$\begin{array}{l}\text { Std. } \\
\text { Error } \\
\text { Mean }\end{array}$} & \multicolumn{2}{|c|}{$\begin{array}{l}95 \% \text { Confidence Interval } \\
\text { of the Difference }\end{array}$} & & \\
\hline & & & & & Lower & Upper & & \\
\hline Pair 1 & $\begin{array}{l}\text { Post-test - } \\
\text { Pre-test } 1 \\
\end{array}$ & 23.51 & 17.12 & 4.04 & 15.00 & 32.03 & 5.8317 & .00 \\
\hline
\end{tabular}




\section{Discussion}

The findings of this research concur with previous studies (Toh et al., 2017, 2019; Azamain et al., 2020; Batrisyia et al., 2020; Musa et al., 2020) that have found using comics to encourage positive attitudes in students towards the lesson or subject. For example, how the study by Hosler and Boomer (2011) investigated non-science majors and their responses to comics when being introduced to science subjects. Still, if there is a general agreement that comics do aid students in helping them be engaged. Then there is a point to consider that comics may be able to help alongside the textbooks as well as perhaps give some ease to allowing students with lower linguistic skills to understand science concepts, such as an alternative to paragraphs of text, or being passively taught. Students were motivated to participate in reading the comics together with the activities carried out related to the comics. However, the lack of studies based on students' views on comics would mean a dearth in referencing precedents of such records to refer to, in addition to conflicting studies that show no effect on knowledge despite the significant impact on engagement (Rofii et al., 2018; Ahmad et al., 2017; Spiegel et al., 2013), and other studies showing a significant improvement in both knowledge and engagement (Lin et al., 2015).

\section{CONCLUSIONS}

Overall, this study revealed there is indeed a positive impact in the use of comics to support learning in the science classroom. Students in the study also viewed comics as favorable as comics were highly engaging and enjoyable to them. With the positive results in using comics in teachings, teachers could use this as one of the supporting tools in their science teaching. Teachers who want to use comics in their teaching should make thorough preparation and should be committed as comic making is labor-intensive. This study has its limitation as it is an action research study utilizing a mixed-method approach and conducted in one classroom. Therefore, the study is not generalizable. Further research should be done with more data to improve the credibility of the study and to explore the use of comics on various science concepts.

\section{ACKNOWLEDGEMENT}

The authors would like to thank all teachers and students who volunteered to participate in the study.

\section{REFERENCES}

Adnan, M., Abdullah, J. M., Ibharim, L. F. M., Hoe, T. W., Janan, D., Abdullah, N., Idris, N., Abdul Wahab, A, S. ... \& Baharudin, N. F. A. (2019). Expanding opportunities for science, technology, engineering and mathematics subjects teaching and learning: Connecting through comics. The Malaysian Journal of Medical Sciences, 26(4), 127-133. https://doi.org/10.21315/mjms2019.26.4.15

Ahmad, S., Prahmana, R. C. I., Kenedi, A. K., Helsa, Y., Arianil, Y., \& Zainil, M. (2018). The instruments of higher order thinking skills. Journal of Physics: Conference Series, 943(1), 012053. https://doi.org/10.1088/1742-6596/943/1/012053 
Akram, T. M., Ijaz, A., \& Ikram, H. (2017). Exploring the factors responsible for declining students' interest in chemistry. International Journal of Information and Education Technology, 7(2), 88-94. https://doi.org/10.18178/ijiet.2017.7.2.847

Azamain, M. S., Shahrill, M., Musa, N. K. H., \& Batrisyia, I. (2020). How using comics can assist in determining the students' learning of distance-time graphs. Journal of Physics: Conference Series, 1470(1), 012005. https://doi.org/10.1088/17426596/1470/1/012005

Barmby, P., Kind, P. M., \& Jones, K. (2008). Examining changing attitudes in secondary school science. International Journal of Science Education, 30(8), 1075-1093. https://doi.org/10.1080/09500690701344966

Batrisyia, I., Shahrill, M., Azamain, M. S., \& Musa, N. K. H. (2020). Captivating primary school pupils' interests in solving mathematics word problems with the use of comics. Journal of Physics: Conference Series, 1470(1), 012006. https://doi.org/10.1088/1742-6596/1470/1/012006

George, R. (2006). A cross-domain analysis of change in students' attitudes toward science and attitudes about the utility of science. International Journal of Science Education, 28(6), 571-589. https://doi.org/10.1080/09500690500338755

Gottfried, A. E., Marcoulides, G. A., Gottfried, A.W., Oliver, P. H. (2009) A latent curve model of parental motivational practices and developmental decline in math and science academic intrinsic motivation. Journal of Educational Psychology, 101(3), 729-739. https://doi.org/10.1037/a0015084

Grunwald, P. (2003). Key technology trends: Excerpts from new survey research findings. Exploring the Digital Generation, Educational Technology, US Department of Education, Washington, DC.

Hosler, J., \& Boomer, K. B. (2011). Are comic books an effective way to engage nonmajors in learning and appreciating science? CBE-Life Sciences Education, 10(3), 309-317. https://doi.org/10.1187/cbe.10-07-0090

Jampel, I., Fahrurrozi, F., Artawan, G., Widiana, I., Parmiti, D., \& Hellman, J. (2018). Studying natural science in elementary school using NOS-oriented cooperative learning model with the NHT type. Jurnal Pendidikan IPA Indonesia, 7(2), 138146. https://doi.org/10.15294/jpii.v7i2.9863

Leong, S. S. M., Said, H. M., Shahrill, M., \& Perera, J. S. H. (2016). Using lesson study to enhance meaningful understanding on the topic of pressure. International Journal of Environmental and Science Education, 11(15), 8425-8437.

Lesmono, A., Bachtiar, R., Maryani, M., \& Muzdalifah, A. (2018). The instructionalbased andro-web comics on work and energy topic for senior high school students. Jurnal Pendidikan IPA Indonesia, 7(2), 147-153. https://doi.org/10.15294/jpii.v7i2.14245

Lin, S. F., Lin, H. S., Lee, L., \& Yore, L. D. (2015). Are science comics a good medium for science communication? The case for public learning of nanotechnology. International Journal of Science Education, Part B, 5(3), 276-294. https://doi.org/10.1080/21548455.2014.941040

Liu, J. (2004). Effects of comic strips on L2 learners' reading comprehension. TESOL Quarterly, 38(2), 225-243. https://doi.org/10.2307/3588379

Matuk, C., Hurwich, T., Spiegel, A., \& Diamond, J. (2019). How do teachers use comics to promote engagement, equity, and diversity in science classrooms? Research in Science Education, 1-48. https://doi.org/10.1007/s11165-018-9814-8

McCloud, S. (1993). Understanding comics: The invisible art. New York: HarperCollins.

Musa, N. K. H., Shahrill, M., Batrisyia, I., \& Azamain, M. S. (2020). Incorporating the use of comics in the secondary mathematics teaching of the order of operations. 
Journal of Physics: Conference Series, 1470(1), 012004. https://doi.org/10.1088/1742-6596/1470/1/012004

Osborne, J., Simon, S., \& Collins, S. (2003). Attitudes towards science: A review of the literature and its implications. International journal of science education, 25(9), 1049-1079. https://doi.org/10.1080/0950069032000032199

Othman, R., Shahrill, M., Mundia, L., Tan, A., \& Huda, M. (2016). Investigating the relationship between the student's ability and learning preferences: Evidence from year 7 mathematics students. The New Educational Review, 44(2), 125-138. https://doi.org/10.15804/tner.2016.44.2.10

Potvin, P., \& Hasni, A. (2014). Analysis of the decline in interest towards school science and technology from grades 5 through 11. Journal of Science Education and Technology, 23(6), 784-802. https://doi.org/10.1007/s10956-014-9512-х

Rofii, A., Sunardi, S., \& Irvan, M. (2018). Characteristics of students' metacognition process at informal deduction thinking level in geometry problems. International Journal on Emerging Mathematics Education, 2(1), 89-104. http://dx.doi.org/10.12928/ijeme.v2i1.7684

Roslan, R., Panjang, S. M., Yusof, N., \& Shahrill, M. (2018). Teacher's feedback in teaching science in a bilingual Bruneian primary classroom. On the Horizon, 26(2), 122-136. https://doi.org/10.1108/OTH-09-2017-0080

Seedhouse, P. (2004). The interactional architecture of the language classroom: A conversation analysis perspective. Malden: Blackwell.

Singh, K., Granville, M., \& Dika, S. (2002) Mathematics and science achievement: effects of motivation, interest, and academic engagement. The Journal of Educational Research, 95(6), 323-332. https://doi.org/10.1080/00220670209596607

Spiegel, A. N., McQuillan, J., Halpin, P., Matuk, C., \& Diamond, J. (2013). Engaging teenagers with science through comics. Research in Science Education, 43(6), 2309-2326. https://doi.org/10.1007/s11165-013-9358-x

Tajmel, T. (2010). DaZ-Förderung im naturwissenschaftlichen Fachunterricht [Second language support in science lessons]. B. Ahrenholz (ed.), Fachunterricht und Deutsch als Zweitsprache [Content-specific subject and German as a second language lessons] (pp. 167-184). Tübingen: Narr.

Tapa, H., Shahrill, M., Tan, A., Mundia, L., \& Abdullah, N. A. (2017). Determining the relationship and influencing factors of high school students' performances and achievements in mathematics. Turkish Online Journal of Educational Technology, 10(1), 792-801.

Tatalovic, M. (2009). Science comics as tools for science education and communication: a brief, exploratory study. Journal of Science Communication, 8(4), A02. https://doi.org/10.22323/2.08040202

Toh, T. L., Cheng, L. P., Ho, S. Y., Jiang, H., \& Lim, K. M. (2017). Use of comics to enhance students' learning for the development of the twenty-first century competencies in the mathematics classroom. Asia Pacific Journal of Education, 37(4), 437-452. https://doi.org/10.1080/02188791.2017.1339344

Toh, T. L., Cheng, L. P., Lim, L. H., \& Lim, K. M. (2019). Shopaholics need mathematics too! Teacher and student perceptions of the use of comics to teach percentage. Australian Mathematics Education Journal, 1(1), 17-23.

Topkaya, Y., \& Doğan, Y. (2020). The effect of educational comics on teaching environmental issues and environmental organizations topics in 7th grade social studies course: A mixed research. Egitim ve Bilim [Education and Science], 45(201), 167-188. https://doi.org/10.15390/EB.2019.8575 
Trnová, E., Trna, J., \&Vacek, V. (2013). The roles of cartoons and comics in science education. In M. F., Dorrio, B. V., \& Kires, M. (Ed.), Proceedings of the 10th International conference on hands-on science (pp. 239-242), 1-5 July, Pavol Jozef Safarik University, Kosice, Slovakia.

Tröbst, S., Kleickmann, T., Lange-Schubert, K., Rothkopf, A., \& Möller, K. (2016). Instruction and students' declining interest in science: An analysis of German fourth-and sixth-grade classrooms. American Educational Research Journal, 53(1), 162-193. https://doi.org/10.3102/0002831215618662

Venturini, P. (2004). Attitudes des élèves envers les sciences: le point des recherches (Note de synthèse). Revue Française de Pédagogie, 149, 97-121.

Xie, Y., \& Achen, A. (2009). Science on the decline? Educational outcomes of three cohorts of young Americans. Population Studies Center Research Report, 9(684), $1-30$. 
Appendix 1: The 15-page comic featuring a leaf fairy character called Nym

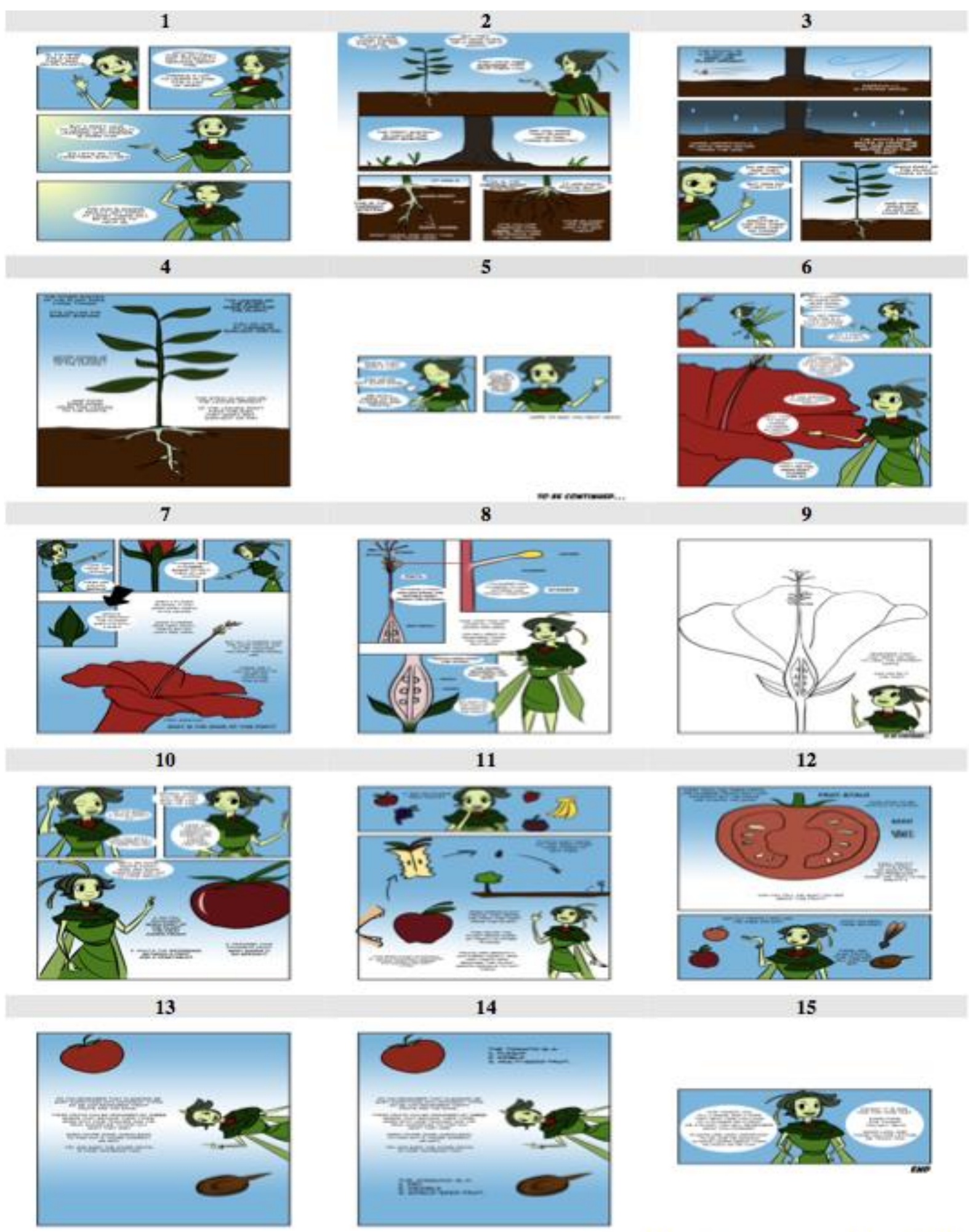

(D) Nym the Leaf Fairy Comic by Phoon et al. 